\title{
PELATIHAN PENULISAN ESAI SEDERHANA DI YAYASAN AL-KAMILAH SERUA DEPOK
}

\author{
Sindy Yulia Putri ${ }^{1}$, Wiwiek Rukmi Dwi Astuti ${ }^{2}$, Yuliani Widianingsih ${ }^{3}$ \\ 123 Universitas Pembangunan Nasional Veteran Jakarta, Jakarta, Indonesia \\ E-mail: sindyyulia@upnvj.ac.id; wiwiek.rukmi@upnvj.ac.id; yulianiwidianingsih@upnvj.ac.id
}

\begin{abstract}
Abstrak
Dalam kemampuan berbahasa, menulis merupakan kemampuan paling akhir dan paling sulit dibandingkan kemampuan lainnya. Menulis membutuhkan waktu yang lama dan motivasi internal yang kuat untuk menyelesaikan tulisan yang telah dimulai. Begitu juga dengan para siswa di Yayasan Al-Kamilah Serua Depok yang juga mengalami kendala dalam mengembangkan tulisan atau karangan sederhana. Maka dari itu, tim pengusul PKM hadir untuk memberikan pelatihan penulisan esai sederhana bagi para siswa SMP dan SMA di Yayasan Al-Kamilah Serua Depok. Tujuan kegiatan ini adalah untuk meningkatkan minat menulis para siswa dan untuk menghasilkan sebuah esai bersama dari pemikiran para siswa di Yayasan Al-Kamilah Serua Depok. Metode pelaksanaan pelatihan ini adalah metode ceramah dan sumbang kalimat untuk membuat satu esai sederhana yang dilakukan secara luring di lokasi yayasan dengan tetap melaksanakan protokol kesehatan covid-19. Metode lain yaitu metode ceramah secara daring melalui ruang virtual di google meet. Hasil dari kegiatan PKM ini adalah sebuah esai sederhana singkat yang dibuat bersama oleh para siswa, peningkatan pengetahuan, dan motivasi para siswa di Yayasan Al-Kamilah Serua Depok dalam menulis esai sederhana.

Kata Kunci:Pelatihan; Penulisan Esai; Siswa; Sumbang Kalimat; Yayasan AIKamilah Serua Depok
\end{abstract}

\begin{abstract}
In language skills, writing is the last and most difficult skill compared to other abilities. Writing takes a long time and a strong internal motivation to complete the writing that has been started. Likewise with students at the Al-Kamilah Serua Depok Foundation who also experienced difficulties in developing simple writing or essays. Therefore, the PKM proposing team was here to provide simple essay writing training for junior high and high school students at the Al-Kamilah Serua Depok Foundation. The purpose of this activity is to increase the students' interest in writing and to produce a joint essay from the thoughts of the students at the Al-Kamilah Serua Foundation, Depok. The method of implementing this training is the method of lecturing and brainstorming a simple essay that is carried out offline at the foundation's location while still implementing the Covid-19 health protocol. Another method is the online lecture method through a virtual space on google meet. The result of this PKM activity is a simple short essay that is made jointly by students, increasing the knowledge and motivation of students at the Al-Kamilah Serua Depok Foundation in writing simple essays.
\end{abstract}

Keywords:Training; Essay Writing; Students; Contribute Sentences; Al-Kamilah Foundation Serua Depok 


\section{PENDAHULUAN}

Menulis menjadi bagian yang tidak terpisahkan dari gaya hidup masyarakat di era revolusi industri 4.0. Setiap orang bisa menulis kapan saja dan di mana saja, baik media cetak maupun elektronik, bergantung pada tujuan penulisannya. Secara fundamental, Widjono (2005:1117) di dalam Rosmiati (2017:1-5) menjabarkan beberapa tujuan menulis, yaitu sebagai sarana berkomunikasi, sebagai sarana mengekspresikan diri, wadah untuk berpikir logis, membangun kecerdasan, mengembangkan kreativitas baru, dan bahkan mengembangkan profesi.

Nyatanya, menulis bukanlah sesuatu yang mudah dan menuntut proses panjang hingga seseorang semakin mumpuni dalam menulis. Bahkan, budaya masyarakat Indonesia masih cenderung pada budaya tutur dan mendengar daripada budaya tulis. Bahkan banyak juga yang lebih suka menjadi pendengar pasif. Ironisnya, begitu banyak orang yang sarat ilmu, namun tidak mengikatnya dengan tulisan. Seiring waktu, ilmu akan mudah terkikis jika tidak dituangkan dalam tulisan. Berbagai gagasan besar juga akan terlupakan jika seseorang tidak menulis Suyanto dan Jihad (2009:115).

Tidak bisa dipungkiri, masih banyak orang mengalami kesulitan dalam menulis. Rahmiati (2014:258-259) di dalam penelitiannya yang berjudul "Analisis Kendala Internal Mahasiswa dalam Menulis Karya IImiah" tahun 2014 menelaah, bahwa sebagian besar mahasiswa mengakui kesulitan menulis karena dua hal, yaitu tidak memiliki waktu dan kesulitan untuk memulai. Mayoritas orang menghadapi kesulitan time management untuk menulis. Selanjutnya, banyak orang yang sulit sekali memulai untuk menulis. Hal ini acap kali terjadi karena seseorang tersebut malas, tidak memahami topik yang akan ditulis, tidak dilatih untuk suka dan sering menulis, dan jarang mengeksplorasi diri untuk menuliskan berbagai ide besar yang bersarang di pikirannya. Hal ini sejalan dengan Suyanto dan Jihad (2009:154) mengemukakan, bahwa kendala yang dihadapi oleh penulis, dari mulai pemula hingga profesional adalah sulitnya untuk memulai menulis sebuah tulisan. Bahkan persentasenya merupakan yang paling tinggi sebagai masalah utama penulis. Lead atau kalimat pembuka sebuah tulisan ilmiah menjadi masalah tersendiri bagi penulis. Penulisprofesional biasanya menyarankan untuk menulis apa saja yang ada di pikiran, kemudian di lain waktu akan disunting. Selama masih linier dengan topik tulisan, maka tidak ada salahnya untuk menulis apa saja yang terpatri di pikiran saat itu juga. Bahkan mereka juga menyarankan untuk mulai menulis tulisan sederhana, seperti esai.

Mengacu pada pemikiran Zemach \& Rumisek (2010:56), esai adalah sekelompok paragraf yang berisi substansi satu topik permasalahan atau 
gagasan utama. Sebuah esai setidaknya memiliki tiga hingga lima paragraf utuh untuk dikategorikan sebagai karya penulisan akademik. Kemudian Davies (2017:3) memaknai esai sebagai sebuah karangan prosa yang membahas suatu masalah dari persspektif penulis. Esai bersifat non-fiksi tetapi seringkali subjektif; sementara ekspositori, mereka juga bisa memasukkan narasi. Esai dapat berupa kritik, kajian politik, argumen penulis mengenai sesuatu yang sedang diteliti atau dipelajari, pengamatan kehidupan sehari-hari, ingatan, dan refleksi penulis dari suatu kejadian (University of Babylon, 2014:1). Esai biasanya hanya berkisar pada 1000-3000 kata dengan struktur sederhana, yaitu introduction (pendahuluan), body (pembahasan), dan conclusion (kesimpulan). Esai sendiri memiliki beragam bentuk, seperti esai deskriptif, esai argumentatif, esai naratif, esai komparatif (perbandingan), esai persuasif, dan esai argumentatif (University of Canterbury, 2015:1-2).

Davies (2017:4) selanjutnya menerangkan, bahwa menulis esai bukanlah hal mudah dan membutuhkan latihan khusus. la menyarankan, agar seseorang menyisihkan waktu selama empat minggu untuk esai formal dengan substansi 4000 kata. Sejalan dengan Davies, Suyanto dan Jihad (2009:154) menginterpretasikan, bahwa menulis esai juga membutuhkan proses, waktu, komitmen, dan motivasi sendiri dari penulis. Motivasi untuk menulis bisa dimulai dari trivial-individual hingga selfactualization, yang berarti, menulis sudah merupakan sebuah kebutuhan yang akan diaktualisasikan sendiri oleh seseorang tanpa disuruh atau dituntut olehsiapapun. Bagi para siswa misalnya, menulis bisa dimulai dari berbagai hal kecil, seperti tugas sekolah ataupun buku harian (diary) untuk mengungkapkan segala kejadian yang dialami setiap hari. Banyak orang muda khususnya generasi milenial saat ini yang mengakui, bahwa menulis membutuhkan inspirasi. Bagi para profesional, inspirasi mungkin sudah terstruktur dan terpatri di ingatan mereka. Namun untuk penulis pemula, inspirasi perlu ditemukan dan digali lagi, sehingga disarankan untuk membawa catatan kecil (note) dan bahkan mencatat di gawai sendiri, jika menemukan ide menarik untuk ditulis (Suyanto \& Jihad, 2009:154).

Mengacu pada penjelasan di atas, maka pelatihan menulis esai sederhana menjadi penting untuk dilakukan. Menulis bisa menjadi ranah aktualisasi diri untuk siapapun, terkhusus bagi para siswa yang berkelindan dengan berbagai teks dan tulisan yang harus dicerna setiap hari, sehingga menjadi bahan pembelajaran untuk berbagi ilmu, khasanah pengetahuan dan pengalaman, bagi penulis itu sendiri maupun bagi para pembaca. Secara khusus, kegiatan pelatihan menulis esai sederhana ini bertujuan untuk meningkatkan minat menulis dan kemampuan menulis para siswa SMP dan SMA di Yayasan Al- 
Kamilah Serua Depok.

\section{PERMASALAHAN MITRA}

Yayasan Al-Kamilah Serua Depok merupakan sebuah yayasan yang menaungi berbagai siswa di tingkat SD, SMP, dan SMA. Yayasan ini berlokasi di Jl. Serua Raya No. 3, Serua, Kecamatan Bojongsari, Kota Depok, Jawa Barat, 16517. Yayasan ini merupakan wadah belajar para siswa, dari tingkat SD hingga SMA. Mereka belajar agama Islam dan pengetahuan umum lainnya. Para siswa tentunya masih mengikuti pembelajaran di sekolah dengan berbagai mata pelajaran yang berkaitan dengan menulis, seperti mata pelajaran Bahasa Indonesia yang menuntut kemampuan dan kebiasaan menulis. Kemampuan ini biasanya dijawantahkan dalam bentuk esai, artikel, karangan sederhana, pantun, dan berbagai karya prosa lainnya.

Para siswa tentunya juga merupakan generasi milenial yang sudah masuk ke ranah digital sosial media, sehingga memeroleh ruang nyata dan maya yang lebih luas untuk menulis berbagai hal, baik berbentuk story di laman media sosial, maupun menulis di media cetak dan elektronik. Terlebih lagi, era revolusi industri 4.0 semakin memberikan ruang yang lebih leluasa bagi para siswa untuk menulis berbagai hal yang dirasa dan dipikirkan. Maka dari itu, tim PKM dari UPN Veteran Jakarta ingin berbagi ilmu dan knowledge transfer bagi para siswa di Yayasan Al-Kamilah Serua
Depok untuk ikut berpartisipasi dalam pelatihan daring penulisan esai sederhana, demi berkontribusi pada masyarakat untuk meningkatkan kemampuan siswa dalam hal kepenulisan. Pelatihan ini nantinya akan diadakan secara daring, karena Indonesia masih menghadapi pendemi covid-19. Pelatihan ini juga memberikan manfaat untuk para peserta pelatihan untuk lebih berani, mumpuni, dan kompeten dalam menulis ilmiah di media sosial, media cetak, dan elektronik agar lebih nyaman dan bermakna untuk dibaca oleh para pembaca di berbagai media tersebut. Kemitraan ini nantinya akan menghasilkan kegiatan pembelajaran yang kontributif secara daring dan diharapkan dapat terus berlanjut di masa mendatang.

\section{METODE PELAKSANAAN}

Dalam program pengabdian kepada masyarakat ini, metode yang diaplikasikan adalah 1) Pelatihan luring dengan metode sumbang kalimat untuk membuat satu esai sederhana yang dilaksanakan di Yayasan Al-Kamilah Serua Depok dengan tetap mengedepankan protokol kesehatan covid-19, dan 2) Pelatihan daring yang dilaksanakan secara virtual melalui google meet. Keduanya diselenggarakan pada hari Kamis, 27 Mei 2021. Metode sumbang kalimat digunakan untuk menstimulus dan meningkatkan kreativitas para siswa secara spontan dalam menulis esai. Metode ini juga bermanfaat untuk semakin mempererat 
interaksi siswa dengan siswa dan siswa dengan narasumber. Metode ini juga digunakan oleh Yusuf dan Trisiana (2019:109) di program pengabdian mereka. Sumbang kalimat atau lazim disebut dengan curah pendapat (brainstorming) diaplikasikan untuk menggali habis segala sesuatu yang dipikirkan siswa dalam menanggapi isu atau masalah yang dilontarkan pada mereka. Sementara metode daring dilaksanakan karena narasumber tidak dapat hadir pada hari itu. Mitra PKM adalah Yayasan Al-Kamilah Serua Depok. Sejalan dengan metode sumbang kalimat, Wahyuni (2017:138) juga melakukan metode curah pendapat untuk aktivitas blended learning yakni luring dan daring. Pembelajaran didesain di kerangkan blended learning dengan metode curah pendapat untuk membantu peserta didik meningkatkan kemampuan berargumentasi dalam menulis esai argumentatif.

Khalayak sasaran di PkM ini yakni 28 siswa tingkat SMP hingga SMA di Yayasan Al-Kamilah Serua Depok. Pelatihan ini diawali oleh kata sambutan dari Ketua Yayasan Al-Kamilah Serua Depok Ustadz Badruddin, S.Ag., MM. Narasumber di PKM ini adalah tim PKM sendiri, yaitu Sindy Yulia Putri, S.Pd., M.Si dan Wiwiek Rukmi Dwi Astuti, S.IP., M.Si. Sementara Yuliani Widianingsih berperan sebagai moderator. Kemudian media yang digunakan adalah power point, infocus, layar proyektor, canva, google form, dan google meet. untuk kuesioner. Demi memperluas khasanah pengetahuan, tim pengusul juga akan mengundang berbagai narasumber, baik dari tim PKM sendiri maupun dari berbagai pihak yang berkecimpung dalam dunia kepenulisan. Berbagai materi terkait dengan pelatihan penulisan esai sederhana akan disajikan pada para peserta PKM di Yayasan Al-Kamilah Serua Depok.

\section{HASIL DAN PEMBAHASAN}

Pelatihan ini pada akhirnya menghasilkan peningkatan pengetahuan bagi para peserta. Mereka semakin memahami definisi esai, ciri-ciri esai, langkah-langkah menulis esai, dan mereka memiliki keinginan yang besar untuk terus belajar menulis esai di kemudian hari. Hasil lainnya adalah satu esai sederhana berjudul "Kehidupan Santri di Pondok" berhasil dibuat oleh para peserta bersama-sama melalui permainan "Sumbang Kalimat". Selanjutnya, Iuaran berupa video juga telah diunggah ke laman youtube. Peningkatan kemampuan siswa yayasan di bagian ini juga didukung oleh hasil pengabdian masyarakat lain dari Wahyuni (2017:142) yang menyatakan, bahwa $82 \%$ pembelajaran dinyatakan valid dengan penggunaan metode sumbang kalimat untuk menulis esai. Peserta didik Program Studi Tadris Bahasa Inggris STAIN Pamekasan memperoleh kemudahan menulis esai argumentatif dari hasil sumbang kalimat (curah pendapat) di kerangka luring dan daring. Selanjutnya, Sakaria dan Nojeng 
(2018:74) yang merupakan dosen di Prodi Pendidikan Bahasa dan Sastra Indonesia Universitas Muhammadiyah Makassar juga menggunakan metode sumbang kalimat untuk merangsang mahasiswa dalam menulis opini dan esai di kelas. Hasilnya, melalui metode sumbang kalimat, mahasiswa semakin terstimulus untuk membuat opini dan esai yang apik sesuai kaidah ilmiah. Nilai pre-test sebesar 74,5. Sementara nilai akhir post-test sebesar 86,2. Metode sumbang kalimat dinilai efektif untuk meningkatkan minat dan kreativitas mahasiswa menulis opini dan esai.

\section{a. Pengisian Kuesioner Sebelum Pelatihan}

Tim PKM membagikan kuesioner sebelum pelatihan kepada para peserta yang berisi beragam pertanyaan dan pernyataan mengenai pelatihan menulis esai, yakni:

1. Apakah kamu senang menulis?

2. Menurut kamu, apakah seseorang perlu motivasi untuk menulis?

3. Apakah kamu sudah memahami definisi esai, ciri-ciri esai, dan jenisjenis esai?

4. Esai adalah tulisan singkat yang dapat dibaca dalam waktu singkat dan membahas suatu topik menarik dari sudut pandang atau pemikiran penulisnya.

5. Apakah kamu sudah memahami langkah-langkah menulis esai sederhana?

6. Bagian pendahuluan esai berisi latar belakang mengapa penulis memilih topik yang akan ditulis.

7. Setelah bagian pendahuluan, bagian selanjutnya dari sebuah esai sederhana adalah

8. Esai cukilan watak merupakan esai yang menceritakan sedikit watak seseorang mengenai suatu topik kepada para pembacaa.

9. Kompas, Tempo, Detik, Analisa, Financial Times, Daily and Sunday Telegraph, The Times adalah beberapa sumber media massa untuk mencari bahan menulis.

10. Manakah yang lebih mudah menurut kamu, apakah mengembangkan ide kunci di awal paragraf (deduktif) atau di akhir paragraf (induktif)?

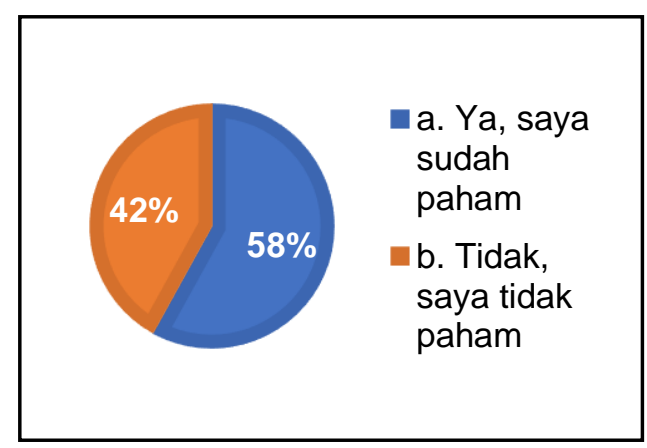

\section{Grafik 1. Pemahaman Siswa mengenai Langkah Menulis Esai Sebelum Pelatihan}

Melalui grafik 1 di atas dapat diperhatikan, bahwa hanya 58\% siswa yang paham mengenai langkah-langkah menulis esai. Mereka masih mengalami kesulitan dalam mengemukakan apa saja langkah-langkah ataupun tahapan menulis esai. Mereka juga memiliki pengetahuan yang masih sedikit mengenai seluk beluk esai sederhana sebelum mengikuti pelatihan. Kemudian grafik 2 berikutnya merepresentasikan 
pemahaman siswa mengenai esai cukilan watak. Hanya $40 \%$ siswa yang menjawab dengan benar mengenai definisi esai cukilan watak. Sebanyak 60\% lainnya masih belum mengetahui mengenai esai cukilan watak.

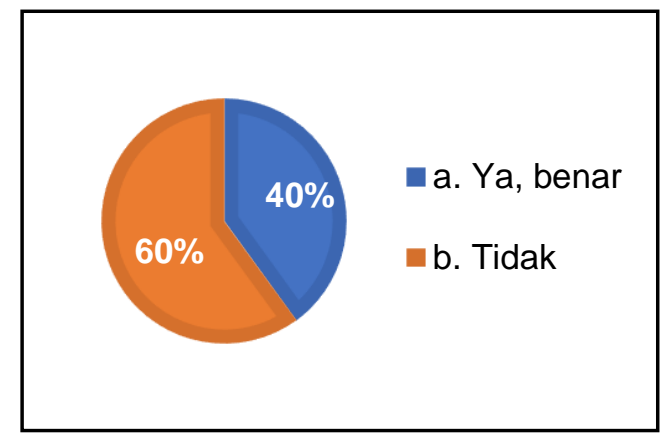

Grafik 2. Jawaban Siswa mengenai Esai Cukilan Watak Sebelum Pelatihan

\section{b. Pengisian Kuesioner Setelah Pelatihan}

Kemudian tim PKM juga menyebarkan kuesioner pasca pelatihan dengan beberapa pertanyaan berikut.

1. Apakah kamu merasa pelatihan ini bermanfaat?

2. Apakah kamu sudah memahami definisi esai, ciri-ciri esai, dan jenisjenis esai?

3. Esai adalah tulisan singkat yang dapat dibaca dalam waktu singkat dan membahas suatu topik menarik dari sudut pandang atau pemikiran penulisnya.

4. Apakah kamu sudah memahami langkah-langkah menulis esai sederhana?
5. Bagian pendahuluan esai berisi latar belakang mengapa penulis memilih topik yang akan ditulis.

6. Setelah bagian pendahuluan, bagian selanjutnya dari sebuah esai sederhana adalah?

7. Esai cukilan watak merupakan esai yang menceritakan sedikit watak seseorang mengenai suatu topik kepada para pembaca.

8. Kompas, Tempo, Detik, Analisa, Financial Times, Daily and Sunday Telegraph, The Times adalah beberapa sumber media massa untuk mencari bahan menulis.

9. Manakah yang lebih mudah menurut kamu, apakah mengembangkan ide kunci di awal paragraf (deduktif) atau di akhir paragraf (induktif)?

10. Setelah pelatihan ini, maukah kamu lebih rajin menulis esai sederhana? Adapun hasil kuesioner di atas dituangkan dalam beberapa grafik selanjutnya.

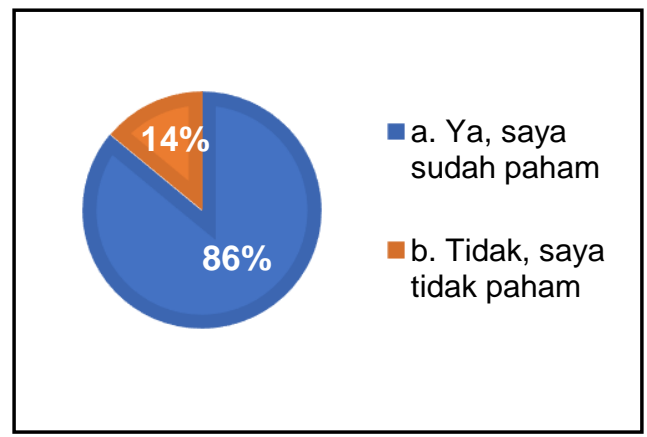

Grafik 3. Pemahaman Siswa mengenai Langkah Menulis Esai Setelah Pelatihan

Grafik 3 di atas mendeskripsikan, bahwa lebih dari setengah siswa yaitu sebesar $86 \%$ telah memahami langkah-langkah menulis esai sederhana, yakni 1) 
Menentukan topik; 2) Menyiapkan outline (garis besar topik); 3) Mengumpulkan materi (studi literatur); 4) Menguraikan isi; 5) Membaca ulang; 6) Memberikan esai ke teman (proof read); 7) Merevisi dan menyempurnakan esai. Mereka juga memahami bagian-bagian utama sebuah esai. Selanjutnya grafik 4 menunjukkan, bahwa sebanyak $70 \%$ siswa menjawab dengan benar, bahwa bagian selanjutnya setelah bagian pendahuluan dari sebuah esai sederhana adalah isi.

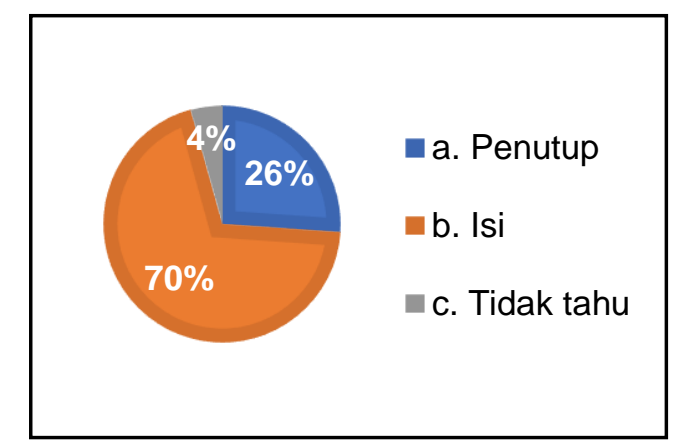

Grafik 4. Pemahaman Siswa mengenai Bagian Utama Esai Setelah Pelatihan

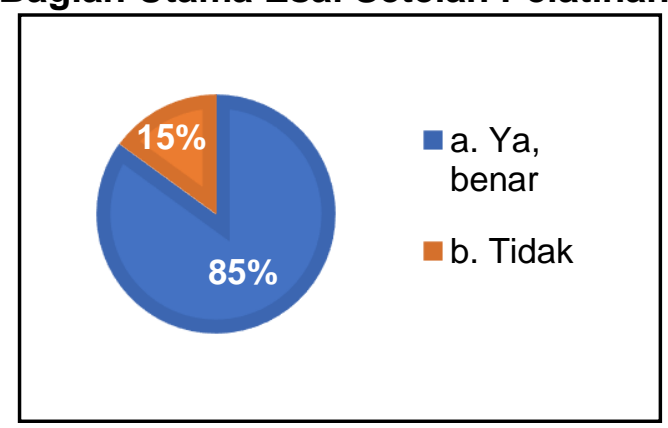

Grafik 5. Jawaban Siswa mengenai Definisi Esai Cukilan Watak Setelah Pelatihan

Kemudian grafik 5 di atas menginformasikan, bahwa $85 \%$ siswa menjawab dengan benar mengenai definisi esai cukilan watak. Mereka memahami, bahwa esai cukilan watak merupakan esai yang menceritakan sedikit watak seseorang di dalam suatu alur cerita.

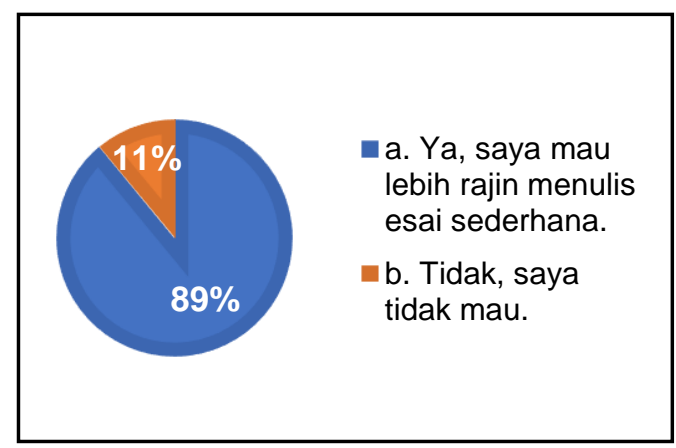

\section{Grafik 6. Minat Siswa untuk Menulis Esai di Masa Mendatang}

Selanjutnya, $\quad$ grafik 6 di atas memperlihatkan minat siswa menulis setelah pelatihan. Sebanyak $89 \%$ siswa menjawab akan lebih rajin menulis esai sederhana di kemudian hari. Mereka terlihat memiliki euforia yang tinggi untuk lebih gemar menulis esai. Terlebih lagi, mereka juga mempunyai beragam tugas menulis di sekolah.

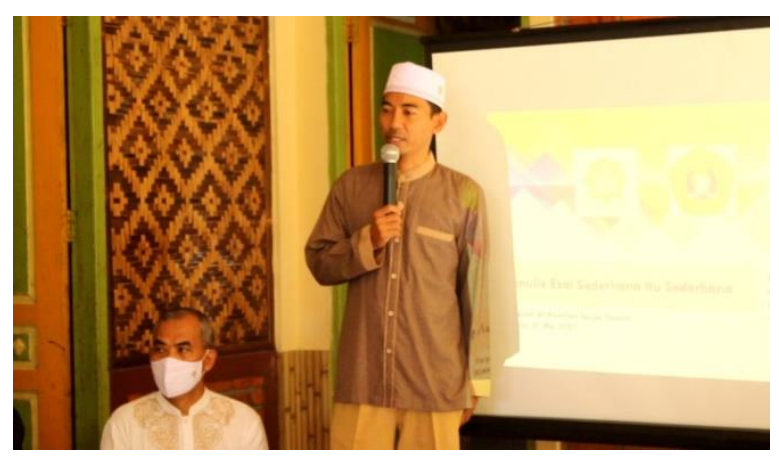

Gambar 1. Sambutan dari Ketua Yayasan Al-Kamilah

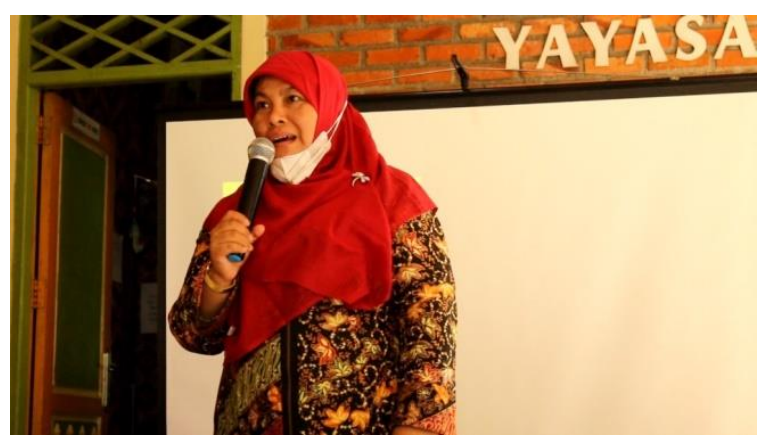




\section{Gambar 2. Pembukaan Acara Pelatihan oleh Moderator}

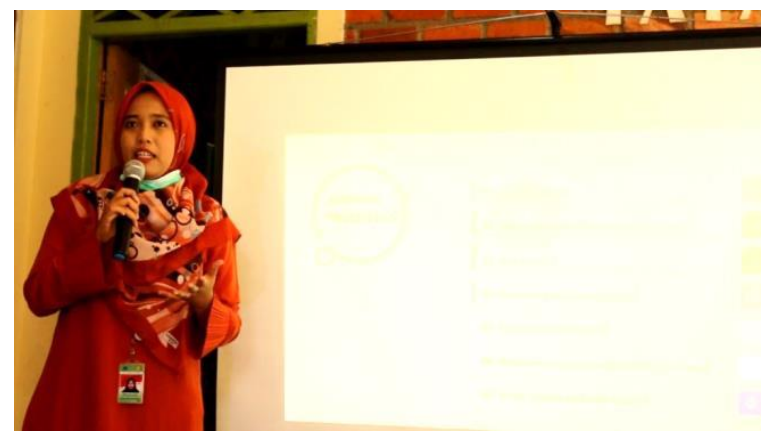

Gambar 3. Paparan dari Narasumber

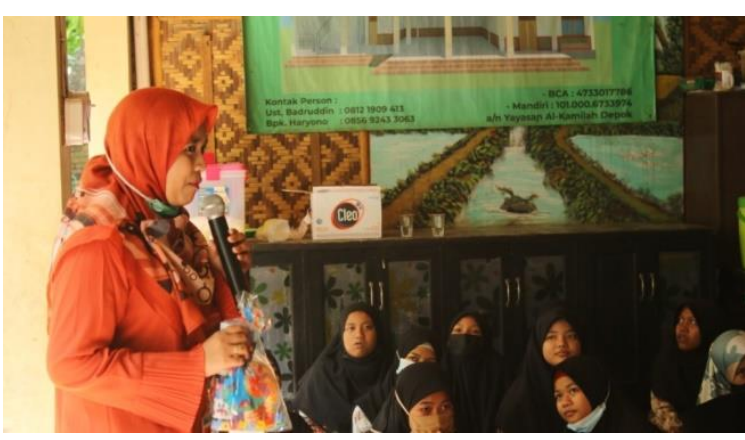

Gambar 4. Permainan Sumbang Kalimat

Ketika permainan "Sumbang Kalimat" dilaksanakan, para siswa sangat senang saat menyambung berbagai kalimat yang dibentuk oleh teman sebelumnya, karena memperoleh souvenir berisi roti, buku tulis, dan pulpen yang dibungkus dengan bingkisan warnawarni. Bahkan satu esai sederhana pun dapat dibuat selama pelatihan berlangsung, dengan judul "Kehidupan Santri di Pondok". Selanjutnya setelah presentasi materi dari kedua narasumber selesai, para peserta menanyakan beberapa pertanyaan, yaitu:

1. Apakah catatan harian (diary) yang saya tulis selama ini bisa menjadi sebuah novel?

2. Bagaimana cara kita tetap semangat dalam menulis?

3. Bagaimana jika kita tidak bisa lagi melanjutkan tulisan kita, karena kehabisan ide di tengah jalan?

Kemudian dua gambar di bawah ini merupakan foto bersama dan penyerahan piagam ucapan terima kasih.

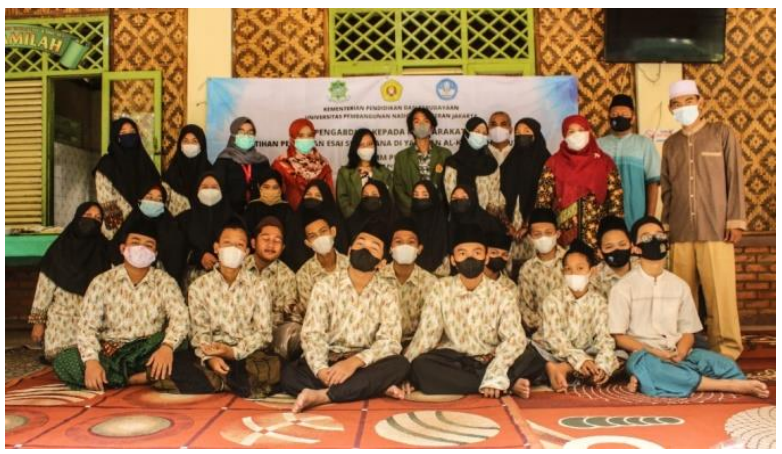

Gambar 5. Foto Bersama

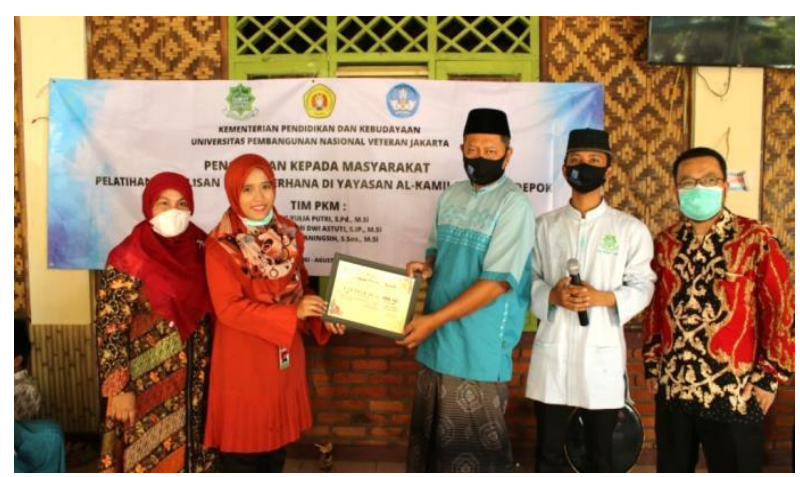

Gambar 6. Foto Penyerahan Piagam Ucapan Terima Kasih

\section{SIMPULAN}

Program PKM dengan judul "Pelatihan Penulisan Esai Sederhana di Yayasan Al-Kamilah Serua Depok" telah selesai diselenggarakan dalam kurun waktu 10 bulan, dari mulai penulisan dan 
pengajuan proposal, pelaksanaan pelatihan luring dan daring, hingga penulisan laporan kemajuan. Program ini merupakan salah satu wujud dharma pengabdian tim dosen IImu Hubungan Internasional dan IImu Komunikasi, FISIP, UPN Veteran Jakarta dalam berkontribusi untuk meningkatkan minat dan pemahaman para siswa di Yayasan AlKamilah Serua Depok mengenai menulis esai sederhana. Kegiatan ini tentunya menambah wawasan siswa di bidang menulis dan dapat diterapkan di sekolah dan aktivitas sehari-hari. Terlebih lagi, media menulis sudah sangat beragam di era revolusi industri 4.0 ini, dari mulai menulis di mading, menulis di buku catatan, menulis di media massa, dan menulis di media sosial. Selama pelatihan, mereka juga berlatih dalam mengungkapkan pemikiran dengan lebih lugas, jelas, dan terstruktur di permainan sumbang kalimat. Kegiatan ini juga menjadi media jalinan kemitraan yang lebih luas dan lebih erat dengan Yayasan Al-Kamilah Serua Depok. Di masa mendatang, tim PKM akan lebih berusaha dalam mengembangkan ilmu pengetahuan dan mengemasnya dengan lebih apik agar program PKM lebih terasa manfaatnya untuk masyarakat mitra.

\section{UCAPAN TERIMA KASIH}

Penulis mengucapkan terima kasih kepada LPPM Universitas Pembangunan Nasional "Veteran" Jakarta yang telah membantu pendanaan program PkM dan terima kasih juga kami haturkan untuk Ketua
Yayasan, Dewan Pengelola Yayasan, para Ustadz, Ustadzah, para ibu dapur, dan siswa/i di Yayasan Al-Kamilah Serua Depok yang telah terlibat dalam pelaksanaan PKM ini. Kemudian, ucapan terima kasih juga kami sampaikan kepada para supir gocar yang telah mengantarkan kami ke lokus PKM dengan selamat.

\section{REFERENSI}

Davies, Martin. (2017). Writing a Research Essay. University of Melbourne, 2-17, https://www.researchgate.net/publica $\underline{\text { tion/312962576 }}$

Rahmiati. (2014). Analisis Kendala Internal Mahasiswa dalam Menulis Karya IImiah. Jurnal AI-Daulah UIN, Vol. 3, No 2, http://journal.uinalauddin.ac.id/index.php/al daulah/ar $\underline{\text { ticle/view/1486 }}$

Rosmiati, Ana. 2017. Dasar-Dasar Penulisan Karya llimah. ISI Press.

Sakaria \& Asis Nojeng. (2018). Bahan Ajar Menulis Opini Dan Esai dengan Pembelajaran Berbasis Proyek. RETORIKA: Jurnal Bahasa, Sastra dan Pengajarannya, ISSN: 2301-4768, 68-76, https://www.researchgate.net/publica tion/326325481 BAHAN AJAR ME NULIS OPINI DAN ESAI DENGAN PEMBELAJARAN BERBASIS PR OYEK/fulltext/5b4606ca458515b4f66 
3c0c9/BAHAN-AJAR-MENULIS-

OPINI-DAN-ESAI-DENGANPEMBELAJARAN-BERBASIS-

PROYEK.pdf

Suyanto \& Asep Jihad. 2009. Betapa Mudah Menulis Karya IImiah. Yogyakarta: CV. Multi Solusindo.

University of Babylon. (2014). What is an Essay?, http://www.uobabylon.edu.iq/eprints/ publication 118749 1861.pdf

University of Canterbury. (2015). Academic Essays: Form and Function,

http://www.lps.canterbury.ac.nz/lsc/d ocuments/essay structure.pdf

Wahyuni, Firda Ayu. (2017). Blended Learning: Dua Metode (Synchronous And Asynchronous) untuk Matakuliah Writing Materi Argumentative Essay. JINOTEP, Vol. 3, No 2, 137-143, https://media.neliti.com/media/public ations/334650-blended-learning-duametode-synchronous-228a34f4.pdf

Yusuf \& Anita Trisiana. (2019). Metode Brainstorming Tertulis: Teknik Curah Pendapat Dengan Memaksimalkan Keterlibatan Semua Peserta Dalam Pengambilan Keputusan. ADIWIDYA: Jurnal Pengabdian Masyarakat Universitas Slamet Riyadi, Vol. 3, No. 2 , 108-116, https://www.researchgate.net/publica tion/343278666 Metode Braistormin g Tertulis Teknik Curah Pendapat Dengan Memaksimalkan Keterlibata n Semua Peserta Dalam Pengamb ilan Keputusan

Zemach, Dorothy E., \& Lisa A Rumisek. 2010. Academic Writing: From Paragpraph to Essay. Spanyol: MACMILLAN. 